\title{
Repair of amalgam restorations with conventional and bonded amalgam: an in vitro study
}

\author{
Reparo de restaurações de amálgama com amálgama adesivo \\ e convencional: estudo in vitro
}

\begin{abstract}
Purpose: This study evaluated microleakage on amalgam restorations repaired by amalgam and bonded amalgam.

Methods: Thirty extracted human pre-molars were restored by amalgam. A simulated defect was prepared and assigned to two treatment groups $(n=15)$ : $G 1$ - repaired by amalgam (Permite C-SDI); G2 - repaired by bonded amalgam (Caulk 34\% Tooth Conditioner Gel - Dentsply + Prime \& Bond 2.1 - Dentsply + Permite C- SDI). The teeth were immersed in a 50\% silver nitrate solution, thermocycled and then, sectioned longitudinally through the restoration center and examined by 3 examiners using a stereomicroscope. Microleakage was evaluated in a $0-4$ scale for dye penetration. Microleakage data were analyzed by Kruskal Wallis and Dunn test.

Results: The bonded amalgam technique was significantly the most effective in repair/tooth interfaces sealing (score $0=53.3 \%, P=0.0012$ ). For repair/restoration interfaces, conventional amalgam was also statistically more effective in the sealing (score $0=86.7 \%, P<0.001$ ).

Conclusion: None of materials eliminated microleakage completely. The use of adhesive systems had significant effect on the ability to seal the repair/tooth interface, however, for repair/restoration interface, it can increase microleakage.
\end{abstract}

Key words: Dental leakage; dental amalgam; dental restoration failure

\section{Resumo}

Objetivo: Avaliar a microinfiltração em restaurações de amálgama com reparo em amálgama ou amálgama adesivo.

Métodos: Trinta pré-molares humanos extraídos foram restaurados com amálgama. Simulou-se um defeito nas restaurações reparado com: G1 - amálgama ( $=15)$ (Permite C-SDI); G2 - amálgama adesivo ( $n=15$ ) (Caulk 34\% Condicionador dentário Gel-Dentsply + Prime \& Bond 2.1 - Dentsply + Permite C-SDI). Os dentes foram imersos em solução de nitrato de prata a 50\%, termociclados e então, secionados longitudinalmente através da restauração e examinados por três examinadores usando um estereomicroscópio. A microinfiltração foi avaliada pela penetração de corante com uma escala de 0 a 4 . Diferenças entre os grupos foram verificadas pelos testes Kruskal Wallis e Dunn.

Resultados: Na interface reparo/dente, a técnica de reparo com amálgama adesivo foi significativamente mais efetiva, apresentando menor microinfiltração (escore $0=53.3 \%, P=0,0012$ ). Já na interface reparo/restauração, houve menor microinfiltração nas restaurações reparadas com amálgama convencional (escore $0=86.7 \%, P<0,001$ ).

Conclusão: Nenhum dos materiais eliminou a microinfiltração completamente. $O$ uso de sistemas adesivos tem efeito significativo no selamento da interface reparo/dente, entretanto para interface reparo/restauração, ele pode aumentar a microinfiltração.

Palavras-chave: Infiltração dentária; amálgama dentário; falha de restauração dentária

\author{
Daniela Araúio Veloso Popoff a \\ Fabiana Santos Gonçalves a \\ Raquel Conceição Ferreira b \\ Cláudia Silami Magalhães c \\ Allyson Nogueira Moreira c \\ Ivar A Miör d
}

a Doctorate Program, School of Dentistry, Federal University of Minas Gerais, Belo Horizonte, MG, Brazil

b Department of Dentistry, State University of Montes Claros, Brazil

c Department of Restorative Dentistry, School of Dentistry, Federal University of Minas Gerais, Brazil

dDepartment of Operative Dentistry, Health Science Center, College of Dentistry, University of Florida, USA

\author{
Correspondence: \\ Raquel Conceição Ferreira \\ Universidade Estadual de Montes Claros/CCBS/ \\ Departamento de Odontologia \\ Av. Rui Braga S/N - Vila Mauricéia \\ Montes Claros, MG - Brasil \\ 39400-000 \\ E-mail: ferreirarc@hotmail.com
}

Received: September 28, 2009

Accepted: February 21, 2010

Conflict of Interest Statement: The authors state that there are no financial and personal conflicts of interest that could have inappropriately influenced their work.

Copyright: (C) 2010 Popoff et al.; licensee EDIPUCRS. This is an Open Access article distributed under the terms of the Creative Commons AttributionNoncommercial-No Derivative Works 3.0 Unported License. 


\section{Introduction}

Dental amalgam has been used in dentistry for over a century. Despite poor esthetic characteristics, lack of adhesion and advancements in resin-based composite technology, amalgam restorations is still one of the restorative treatment options in several dental practice (1-3). Such popularity can be attributed to its good clinical performance, relatively low cost and long-term cost-effectiveness (2). Secondary caries and fractures are common failures related to amalgam restorations and represent the main reasons for their replacement of defective amalgam restorations $(1,3,4)$.

Total replacement is the most common treatment for defective amalgam restorations $(1,4)$ and represents a major part of restorative dental treatment. However, this approach contradicts the current trend for more conservative procedures to minimize the chances of pulpal injuries and to save tooth structures. An aim for current restorative dentistry is to maintain restorations, i.e., to work with materials and techniques that allow the repair of localized defects (5).

Repair is an alternative option for treatment of defective amalgam restoration. It involves the removal of part of the restoration and any defective tissue adjacent to the defective area and restoration of the prepared site (6). This procedure allows preservation of sound tooth structure (7).

Marginal sealing of amalgam restorations remains a challenge in clinical practice $(1,8,9)$. The use of amalgam bonding agents has become a popular clinical practice in the restoration of posterior teeth, showing potential advantages including tooth reinforcement, decreased postoperative sensitivity, better marginal adaptation, decreased microleakage, reduced possibility of secondary caries and more conservative preparation (10-12).

Many resin adhesives have been employed and successful reports indicate their effectiveness as amalgam bonding agents. Bond strength values and sealing data vary considerably among the materials employed based on the way they are applied (12), and possible influence by cavity size, indicating that bond strength is inversely proportional to the bonding area $(3,13)$.

Meanwhile, in a recent systematic review, authors concluded that there is no evidence to either claim or refute a difference in survival between bonded and non-bonded amalgam restorations (14). In view of the lack of evidence on the additional benefit of adhesively bonding amalgam in comparison with non-bonded amalgam, it is important to investigate if is desirable to use this technique for specific situations like for making repairs. Despite the limitations of in vitro studies in predicting clinical conditions, this study may help in the construction of the scientific evidence body to justify or not the inclusion of bonded amalgam in the therapeutic arsenal of dentistry.

Thus, the objectives of this study were to evaluate the microleakage of amalgam repairs when a bonding agent is applied. The null hypothesis tested was the microleakage at amalgam repair margins is not affected by the using of bonding agents.

\section{Methods}

This study was approved by the UNIMONTES Ethics Committee, number 105/19-07-2004.

\section{Teeth Selection}

Thirty non-carious human premolars freshly extracted for orthodontics purposes were employed in this study. The roots were cleaned by scraping to remove debris and disinfected in $0.5 \%$ thymol solution before use.

\section{Specimen Preparation}

Class I cavity preparations were cut on the occlusal surface, $2 \mathrm{~mm}$ wide $\mathrm{X} 4 \mathrm{~mm}$ deep X $3 \mathrm{~mm}$ long, using a high speed handpiece with air-water coolant and a carbide plain fissure bur \# 245 (KG Sorensen Ind \& Com Ltda, Barueri, SP Brazil). The burs were replaced after five cavity preparations. Preparation dimensions were measured with a periodontal probe to maintain uniformity. One operator prepared all teeth to ensure a consistent calibrated size and depth in order to minimize preparation variability.

\section{Restorative procedure}

The teeth were then restored by an admixed, high copper amalgam alloy (Permite C, SDI, Bayswater, Victoria, Australia) that was hand condensed into the preparations covering all walls and cavosurface margins, then carved to the tooth contour with a sharp carve. Seventy two hours later, restorations were polished and stored in saline solution at $37^{\circ} \mathrm{C}$. All restorative procedures were performed by one trained operator.

\section{Repair procedure}

New Class I cavity preparations ( $1 \mathrm{~mm}$ wide X $2 \mathrm{~mm}$ deep X $3 \mathrm{~mm}$ long) were prepared along the cavosurface margin of the amalgam restorations in order to simulate a defect. A high speed handpiece with air-water coolant and carbide plain fissure burs \# 245 (KG Sorensen Ind \& Com Ltda, Barueri, SP Brazil) were used. The burs were replaced after five cavity preparations. Preparation dimensions were measured with a periodontal probe to maintain uniformity. One operator prepared all teeth to ensure a consistent calibrated size and depth in order to minimize preparation variability.

The teeth were randomly divided into two experimental groups ( $\mathrm{n}=15$ ): G1 - Amalgam repairs (Permite C - SDI, Bayswater, Victoria, Australia) and G2 - Bonded amalgam repairs (Caulk 34\% Tooth Conditioner Gel - Dentsply, Milford, Delaware, USA + Prime \& Bond 2.1 - Dentsply, Milford, Delaware, USA + Permite C).

\section{Thermal Cycling and Microleakage testing}

The specimens were subjected to thermal cycling for 500 cycles between $5^{\circ} \mathrm{C}$ and $55^{\circ} \mathrm{C}$ with 60 seconds dwell time. The teeth were apically obturated with glass-ionomer (Ketac Bond - 3M ESPE, St Paul, MN, USA) and then coated with two layers of nail varnish (Niasi, Taboão da Serra, SP, Brazil) leaving the repairs margins uncoated. They were 
then immersed in a 50\% silver nitrate solution for 24 hours at $37^{\circ} \mathrm{C}$ in the absence of light. Next, they were washed in running water and immersed into another vial with photodeveloping solution (Decktol - Kodak, São José dos Campos, SP, Brazil) for 6 hours, under continuous illumination to reduce and precipitate silver ions. Each specimen was sectioned longitudinally by a cutting machine (Labcut 1010 Extec Technologies Inc., USA), in a buccolingual direction through the restoration center. Sections were examined with a stereomicroscope (Zeiss - Oberkochen, Germany) at $50 \mathrm{X}$ magnification by three trained examiners.

\section{Microleakage evaluation}

Each section was graded for microleakage at both repair tooth and repair restoration interfaces as follows (Fig. 1) 0 - No dye infiltration

1 - Dye penetration up to first third of the repair axial wall 2 - Dye penetration up to second third of the repair axial wall
3 - Dye penetration onto repair axial wall

4 - Dye penetration onto pulpal wall of the repair.

\section{Statistical Analysis}

The agreement between examiners was evaluated by Cohen's Kappa test ( $\mathrm{K}=0.78$ to 1.00$)$. For the microleakage data, the scores were subjected to statistical analysis using KruskalWallis and Dunn tests $(P<0.05)$.

\section{Results}

The non-parametric test Kruskal-Wallis detected significant differences between the tested materials for both repair/tooth $(P=0.000)$ and repair/restoration $(P<0.001)$ interfaces.

Dunn test showed that dye penetration was significantly deeper when amalgam was used for sealing of repair/tooth interface $(Z=2.67 ; P=0.0012$ ) (Fig. 2). For repair/restoration interface, dye penetration was significantly deeper when bond amalgam was used ( $\mathrm{Z}=4 ; P=0.000)$ (Fig. 3).
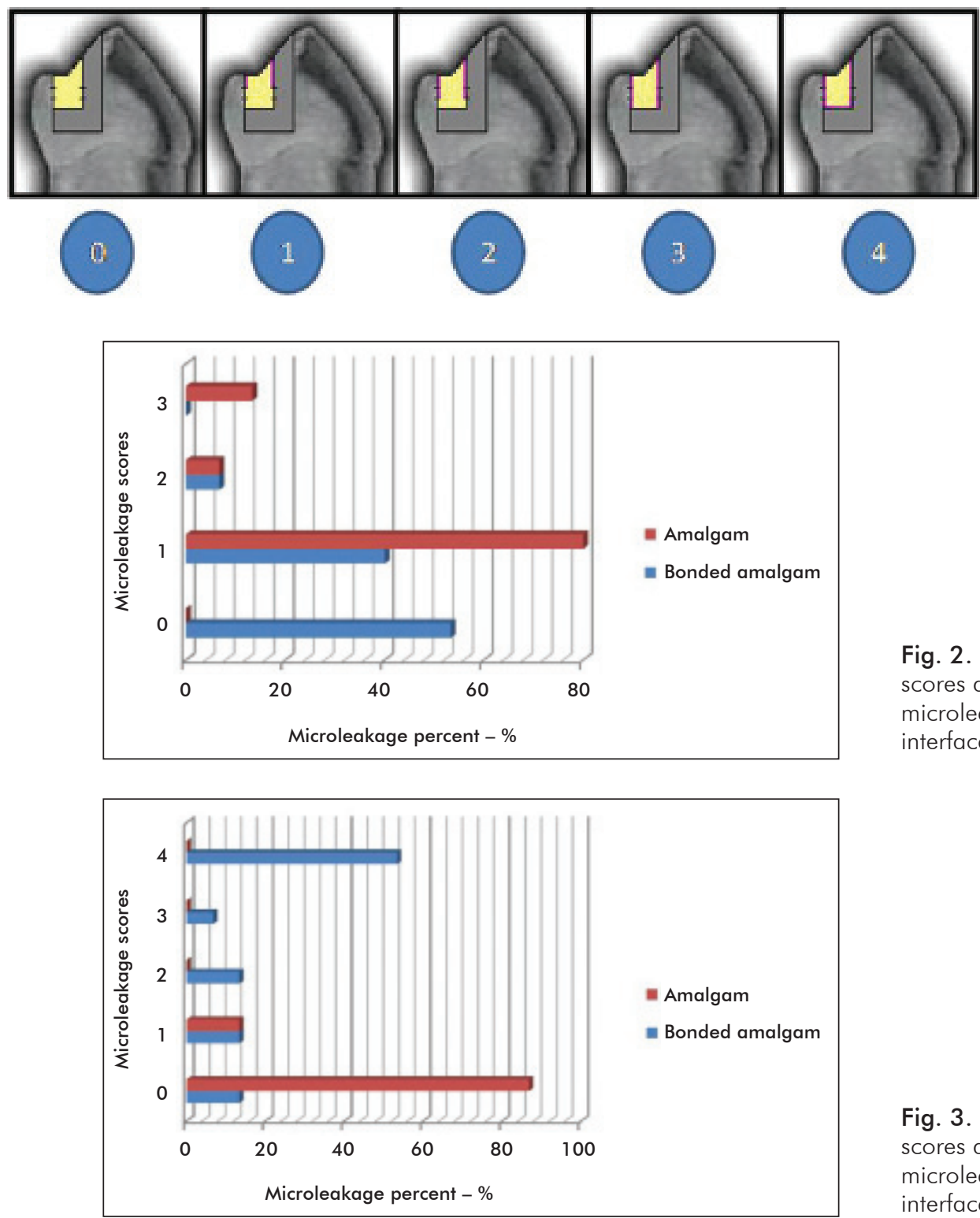

Fig. 1. Dye penetration scores as an indicator of marginal microleakage for repair/tooth and repair/restoration interfaces.
Fig. 2. Percent of dye penetration scores as an indicator of marginal microleakage for repair/tooth interfaces.
Fig. 3. Percent of dye penetration scores as an indicator of marginal microleakage for repair/restoration interfaces. 


\section{Discussion}

Repair of amalgam restorations has been considered to be a viable, cost-effective alternative treatment to complete replacement. It allows removal of localized defects with maximal preservation of tooth structure. Other advantages of repairs are minimal stress on the pulp, simplicity of technique provided access can be made and saving of time and material $(1,5-7,15)$.

Total replacement is the most common treatment for amalgam restoration clinically diagnosed as defective (4). If the presence of active caries cannot be ascertained, dentists should consider repairing the restorations. The selection of cases should include strict clinical and radiographic examination and this technique is not indicated for fracture of restoration body, exposure of the base material, several failures in the same restorations, areas of high concentration of stress, recurrent caries with evidence of extension, especially in patients with high risk of caries (4-6).

It has not been established which restorative procedure would be more appropriate for repair of amalgam restorations. Within the limitations of in vitro and results from in vivo studies, the available data lead to the conclusion that the repairs, when well designed, are effective to increase the longevity of amalgam restorations as indicated by established authors $(4,6,16)$. The present results found marginal sealing in up to $86.7 \%$ for the repair/restoration interface.

Marginal microleakage is a major concern in restorative dentistry as it is related to pulpal changes, sensitivity and development of secondary caries, the most common reason for failure of amalgam restorations (17). Although the methods available to determine microleakage are not well established, dye leakage methodology remains a popular tool to investigate the sealing ability of restorative materials, due to its low cost and simple technique (18). Furthermore, measurements of marginal-sealing effectiveness and bondstrength testing are the two most commonly employed methodologies to determine bonding capacity in laboratory testing (19).

The present study tested the effectiveness of two restorative techniques materials on the marginal microleakage of amalgam repairs, using $50 \%$ silver nitrate solution as tracer. Silver ions, being extremely small $(0.059 \mathrm{~nm})$, have great ability to penetrate tooth-restoration interfaces compared to a bacteria which measure about 0.5 to 1.0 micrometers. In principle, silver could result in an underestimation of the marginal sealing ability of materials from a clinical point of view (20).

Thermal cycling aims to simulate thermal fluctuations of the oral cavity, which imitate what could occur with the restorations under clinical conditions. In this study, the specimens were submitted to thermal cycling for 500 cycles between $\pm 5^{\circ} \mathrm{C}$ and $\pm 55^{\circ} \mathrm{C}$, with 60 seconds of dwell time, long enough to establish thermal equilibrium between specimen and fluid and create tensions capable of breaking the union between them, leading to microleakage (5).
Furthermore, in a previous study about the influence of thermal stress on the marginal integrity of restorative materials with different adhesive, all thermal cycling regimens, 500 and 1000 cycles, increased leakage in all amalgam restorations and its effect on resin based composite and glass ionomer restorations was only significant when a 60-s dwell time was used (21), justifying the regimen and time dwell used in the present study.

Several investigations have reported significant reductions in marginal leakage when adhesives systems were placed under amalgam restorations compared to those with varnish or no liner. The use of adhesive systems associated to amalgam restoration has been a common procedure and studies have shown that this techniques would increase initial sealing, tooth reinforcement, decreased postoperative sensitivity, better marginal adaptation, decreased microleakage, reduced possibility to the secondary caries, and more conservative preparations $(2,6,11,15)$. However, there is a discrepancy between authors about the relevance of these findings. In some studies, no differences in marginal integrity were found for teeth treated with or without adhesive systems $(3,14,22)$.

Despite advantages of adhesive technology, clinical and laboratory studies have found no differences in marginal integrity and postoperative sensitivity for cases treated with or without the use of adhesives $(3,22,23)$. These results are in disagreement with the present findings, which found better sealing when adhesive systems were used for repair tooth interface. However, for repair restoration interfaces, the results are consistent with previous findings in that non-bonded amalgam had lower levels of leakage.

SEM studies have shown occurrence of micromechanical interlocking between amalgam and adhesive, but also demonstrated that most of the adhesion comes from the adhesive/tooth interface (24). The present findings confirm the results from such studies which indicate a reduction of marginal microleakage in amalgam restorations repaired with adhesive when compared to amalgam only for repair/ tooth interfaces, and not for repair/restoration interfaces. The results for repair/restoration interface may be related to the products of corrosion of the amalgam that improve sealing marginal in long-term studies (25).

Thus, the choice for the most suitable material to perform amalgam repair technique highlights the need for clinical studies. Although data indicate non-bonded amalgam as the best procedure to prevent marginal microleakage for repair restoration interfaces, its performance was not suitable for repair tooth interface in short term in vitro studies. Furthermore the bonded amalgam technique could not provide more than $53 \%$ sealing for repair/tooth interface. Knowing the limits of each material is essential for the dentists, and the need for more clinical research about the repair technique is justified by the lack of restorative materials that can provide an optimal marginal adaptation. 


\section{Conclusions}

Within the limitations of this study, the results show that:

- None of the restorative materials evaluated was able to completely eliminate marginal microleakage.

- For repair tooth interface, bonded amalgam had greater sealing ability.

- For repair restoration interface, conventional amalgam showed the lowest level of leakage.

\section{References}

1. Shen C, Speigel J, Miör IA. Repair strength of dental amalgams. Oper Dent 2006;31:122-6.

2. Forss H, Widström E. Reasons for restorative therapy and the longevity of restorations in adults. Acta Odontol Scand 2004;62: 82-6.

3. Silva AF, Piva E, Demarco FF, Correr Sobrinho L, Osinaga PWR. Microleakage in conventional and bonded amalgam restorations: Influence of cavity volume. Oper Dent 2006;31:377-83.

4. Gordan WV, Riley JL, Blaser PK, Miör IA. 2-year clinical evaluation of alternative treatments to replacement of defective amalgam restorations. Oper Dent 2006;31:418-25.

5. Veloso DA, Ramalho LMP. In vitro study of the microleakage on amalgam repairs. RGO 2006;54:317-21.

6. Moncada G, Fernández E, Martin J, Arancibia C, Miör I, Gordan $\mathrm{W}$. Increasing the longevity of restorations by minimal intervention: a two-year clinical trial. Oper Dent 2008;33:258-64.

7. Miör IA, Reep RL, Kubilis PS, Mondragon BE. Change in size of replaced amalgam restorations: a methodological study. Oper Dent 1998;23:272-7.

8. Rossomando Ki, Wendt SL Jr. Thermocycling and dwell times in microleakage evaluation for bonded restorations. Dent Mater $1995 ; 11: 47-51$.

9. Mahler DB, Bryant RW. Microleakage of amalgam alloys: an update. J Am Dent Assoc 1996;127:1351-6.

10. Vargas J, Matsumura H, Masuhara E. Bonding of amalgam filling to tooth cavity with adhesive resin. Dent Mater J 1986;5:158-64.

11. Setcos JC, Staninec M, Wilson NH. Bonding of amalgam restorations: existing knowledge and future prospects. Oper Dent 2000;25:121-9.

12. Muniz M, Quioca J, Dolci GS, Reis A, Loguercio AD. Bonded amalgam restorations: microleakage and tensile bond strength evaluation. Oper Dent 2005;30:228-33.

13. Leloup G, D'Hoore W, Bouter D, Degrange M, Vreven J. Metaanalytical review of factors involved in dentin adherence. J Dent Res 2001;80:1605-14.
14. Fedorowicz Z, Nasser M, Wilson N. Adhesively bonded versus nonbonded amalgam restorations for dental caries. Cochrane Database Syst Rev. 2010 Feb [cited 2010 February 19]; 7: CD007517. Available at: http://mrw.interscience.wiley.com/cochrane/clsysrev/ articles/CD007517/frame.html

15. Machado C, Sanchez E, Alapati S, Seghi R, Johnston W. Shear bond strength of the amalgam-resin composite interface. Oper Dent 2007;32:341-6.

16. Christensen, GJ. When and how to repair a failing restoration. J Am Dent Assoc 2007;138:1605-7.

17. Manhart J, Chen H, Hamm G, Hickel R. Buonocore Memorial Lecture. Review of the clinical survival of direct and indirect restorations in posterior teeth of the permanent dentition. Oper Dent 2004;29:481-508.

18. Raskin A, D'Hoore W, Gonthier S, Degrange M, Déjou J. Reliability of in vitro microleakage tests: A literature review. J Adhes Dent $2001 ; 3: 295-308$.

19. Van Meerbeek B, De Munck J, Yoshida Y, Inoue S, Vargas M, Vijay $P$ et al. Adhesion to enamel and dentin: Current status and future challenge. Oper Dent 2003;28:215-35

20. Alani AH, Toh CG. Detection of microleakage around dental restorations: a review. Oper Dent 1997;22:173-85.

21. Cenci MS, Pereira-Cenci T, Donassolo TA, Sommer L, Strapasson A, Demarco FF. Influence of thermal stress on marginal integrity of restorative materials. J Appl Oral Sci 2008;16:106-10.

22. Davis R, Overton JD. Efficacy of bonded and nobonded amalgam in the treatment of teeth with incomplete fractures. J Am Dent Assoc 2000;131:469-78.

23. Özer F, Ünlü, N. Öztürk B, Sengun. Amalgam repair: evaluation of bond strength and microleakage. Oper Dent 2002;27:199-203.

24. Zardiackas LD, Stoner GE. Tensile and shear adhesion of amalgam to tooth structure using selective interfacial amalgamation. Biomaterials 1983;4:9-13.

25. Gallato A, Reis A, Loguercio AD. Long-term monitoring of microleakage of different amalgams with different liners. J Prosthet Dent 2005;93:571-6. 